\title{
НАУЧНАЯ ПРОБЛЕМАТИКА ИСПОЛЬЗОВАНИЯ РУССКИХ И КИТАЙСКИХ ФРАЗЕОМАТИЗМОВ С КОМПОНЕНТАМИ ДРУГ, ДРУЖБА НА ТРАНСГРАНИЧНОЙ ТЕРРИТОРИИ
}

\section{SCIENTIFIC PROBLEMS OF USING RUSSIAN AND CHINESE PHRASEOMATISMS WITH THE COMPONENTS FRIEND, FRIENDSHIP ON A CROSS-BORDER TERRITORY}

Yan Yuzhuang

O. Ladisova

Summary: This paper analyzes phraseological units with a significant component «friend» and «friendship» of the Russian language against the background of Chinese linguoculture used in stable expressions (phraseological idioms) on the cross-border territory of the Amur region and the city of Blagoveshchensk. The basic concepts of General linguistic theory and the theory of phraseomatics, as a special case of phraseology, served as a prerequisite for writing this work.

Keywords: cross-border area, socio-cultural space, phrasiomatism, chenyu 成, language unit.
$\mathrm{T}$ рансграничье как регион, объединяющий приграничные области двух и более государств в условиях тесного многостороннего взаимодействия, является сферой культурного обмена информацией, при исследовании которого могут быть задействованы все без исключения подходы культурологического знания.

Такое трансграничное взаимодействие предполагает толерантное общение существующих национальных культур в условиях повышения интенсивности коммуникации в новой социальной политической обстановке. Адекватное понимание информации на неродном языке становится затруднительным без знания наиболее употребительных лексических и фразеологических единиц, так как они являются обязательной частью того культурного минимума, который необходим для адекватного общения на том или и ном языке в условиях межкультурной коммуникации.

Устойчивые словосочетания издавна привлекали внимание исследователей. Богатством русской фразеологии, её сбором и осмыслением интересовались Шахматов А.А., Фортунатов Ф.Ф., Срезневский И.И., Покровский М.М., Потебня А.А. , Абакумов С.И., Поливанов Е.Д., Ларин Б.А. и другие ). В китайской фразеологии также как и в русской существует широкое и узкое понимание фразеологических единиц. Многочисленные работы по фра-
Янь Юйчжуан

Аспирант, ФГБОУ ВО «Благовещенский государственный педагогический университет»

13614582298@mail.ru

Ладисова Ольга Владимировна

к.филол.н., дочент, ФГБОУ ВО «Благовещенский государственный педагогический университет» olga-ladisova@yandex.ru

Аннотация: В данной работе произведен анализ фразеологических единиц со значимым компонентом "друг», «дружба» русского языка на фоне китайской лингвокультуры, используемых в устойчивых выражениях (фразеологических идиомах) на трансграничной территории Амурской области, города Благовещенска. Предпосылкой к написанию данной работы послужили основные понятия общелингвистической теории и теории фразеоматики, как частного случая фразеологии.

Ключевые слова: трансграничье, социокультурное пространство, фразиоматизм, ченьюй 成语, языковая единица.

зеологии , идиоматике, фразеоматике доказывают большой интерес лингвистов к изучению таких единиц языка и с китайской стороны (Вань Сэн, Шен Яньлин, Лу Шупин, Сюй Гоицин, Чжан Юнъянь, Ма Гофань, Тань Аошуан , Бао Хун , Цзян Сипин, Го Сини, Цао Юнцзе, Цун Япин, Ли Ли, Юй Шэнбо и другие).

Цель нашего исследования - выявить универсальные сходства и национально-культурные особенности фразеологических единиц (фразеоматизмов) с компонентом «друг», «дружба» в лексико-семантических системах сопоставляемых языков на трансграничной территории России и Китая.

Вслед за В.М. Савицким, Л.В. Молчковой [10] мы разделяем идиомы на фразовые и лексические. Фразовые делятся на фразеоматические и фразеологические. При этом под фразеоматической идиомой будем понимать фразовую идиому с частично транспонированным значением.

Фразеоматизмы для исследования отбирались из наиболее распространённых устойчивых выражений, которые употребляются на трансграничной территории, в которую входит город Благовещенск. Все выражения сопоставлялись с материалами «Фразеологического словаря русского языка» [2] и «Фразеологического сло- 
варя китайского языка» Чжан Шоукана [5]. В ходе работы устойчивые фразеоматизмы китайского языка переведены на русский язык, на первом этапе дословно, на втором этапе подобраны фразеоматизмы - аналоги из устойчивых выражений русского языка, часто используемые на данной территории.

Трансграничный регион, включающий в себя сопредельные территории Китая и России, является уникальным по многим параметрам. Это культурно-историческое пространство, которое объединяет разные по происхождению и конфессиональной принадлежности народы. Насколько велико различие историко-культурного развития русского и китайского народов, настолько интересен процесс исследования их лингвокультурологического взаимодействия.

Город Благовещенск, благодаря своему географическому положению, входит в состав трансграничного региона, который объединяет приграничные области двух государств - Китай и Россия. В процессе тесного взаимодействия двух народов неизбежны социокультурное взаимопроникновение в сфере лингвокульторологических компонентов двух языков.

Ключевым фактором, способствующим развитию коммуникативных связях в различных формах, является освоение русского языка представителями китайской национальности, проживающих и обучающихся на территории города Благовещенска, а так же освоение основ китайского языка представителями русской национальности, в силу различных обстоятельств, взаимодействующими с представителями КНР. В ходе общения, понимание особенностей передаваемой информации, ее адекватное восприятие, невозможно без знания наиболее распространённых устойчивых национальных лексических выражений.

Для определения смысловой нагрузки фразеоматических идиом, используемых коренными представителями китайской культуры, необходим историко-культурный анализ классической и народной литературы Китая. Как в китайском, так и в русском языке, большинство из них берут свое начало из древних трактатов, мифов, легенд и т.д.

В русском языке обнаруживается порядка 70 фразеологических единиц с компонентом «друг», «дружба», среди которых можно выделить разные тематические группы, часто используемые в речи жителей трансграничной территории. Проведенный нами лингвистический эксперимент среди русских студентов позволил выявить наиболее употребляемые на трансграничной территории. Среди которых оказались следующие тематические группы: разные друзья, хорошие друзья, сердечные дела, из соцсетей, польза дружеских отношений, ценность друга, дружеская поддержка, политика, друг другу, круг друзей. Приведем примеры.

В русском языке во фразеоматических идиомах значение только частично транспонированное.

Пример: «Друг ситный».

1. Слово «Друг» в данном выражении не меняет своего значения.

2. «Ситным» называли просеянный через сито хлеб, испечённый из дорогой муки. Хлеб получался пышным и вкусным.

Значение фразеоматической идиомы: хороший друг, ценный, добрый. Таким образом, в русском языке, фразеоматической идиомой (или фразеоматизмом) является идиоматичное сочетание слов нефразеологического характера [5].

В китайском языке также существует определенная классификация фразеоматических единиц. В настоящее время китайский лингвист Ма Гофань (马国凡) выделяет 5 основных разрядов фразеологизмов:

1) ченьюй 成语 - идиомы;

2) яньюй 颜语 - пословицы;

3) сехоуюй 歇后语 - недоговорки-иносказания;

4) гуаньюнъюй 惯用语 - фразеологические сочетания;

5) суюй 俗语 - поговорки [4].

Перечисленные разделы, имеют свои особенности и закономерности, свое историческое значение, однако имеют одну основу и связаны между собой. Для нашего исследования интересны «ченьюй 成语» - идиомы с частично транспонированным значением - аналоги русских фразеоматизмов. Для наиболее глубокого понимания смысловой нагрузки, которое несет каждое из выражений, необходим не точный дословный перевод, который может вызвать затруднения, а подходящее выражение из русского языка с аналогичной смысловой нагрузкой. Для выполнения такого перевода требуется историко-культурный и лингвокультурологический анализ данного выражения с точки зрения носителя языка (в нашем случае китайского).

«Чэнъюй 成语 (букв, «готовое выражение») - это устойчивое фразеологическое словосочетание, построенное по нормам древнекитайского языка, семантически монолитное, с обобщенно переносным значением, носящее экспрессивный характер, функционально являющееся членом предложения» [5, с. 18].

Свойства идиом китайского языка:

- построение в соответствии с нормами древнекитайского языка;

- семантическая целостность;

- наличие переносного значения с экспрессивным характером;

— выполнение функций члена предложения [9]. 
Источник большей части идиом: классические китайские произведения на письменном классическом китайском языке (вэньян). Знание наиболее популярных «чэнъюй» является признаком наличия образования у жителя Китая. В словарях «чэнъюй» объясняется смысл фразеологических оборотов с указанием первоисточника [9].

В ходе исследования нами найдено более 70 устойчивых выражений со словами «Друг», «Дружба» наиболее часто употребляемых в общении на территории города Благовещенска.

В фразеоматизмах, которые употребляются в речи для краткого и образного отображения наблюдаемой ситуации или явления, четко прослеживаются черты национального менталитета, содержится четкая лингвокультурная основа.

Проводя анализ возникновения некоторых из выбранных фразеоматических единиц, можно проследить состав языка в контексте культуры и выявить «зерно» - культурный смысл, отражающий национальное мировоззрение. Их перевод невозможен без знания традиций или истории.

Например: 竹马之交 - друг бамбуковой палочки-лошадки. В древнем Китае при игре дети использовали бамбуковые палочки, изображая наездника на лошади. Таким образом данное выражение в наши дни означает дружбу с детства.

Некоторые, фразеоматические идиомы китайского языка, составлены по аналогии с фразеоматическими идиомами русского языка и не теряют своего значения и не требуют дополнительной информации при дословном переводе. Пример:

严师不如益友。- Задушевный друг лучше строгого учителя. В русском переводе этот фразеоматизм можно интерпретировать - «Закадычный друг».

В древней Руси слово «закадычный» означало - духовно близкий. Считалось, что душа человека расположена в небольшой полости за кадыком (между ключицами). Следовательно, фразеоматизм «Закадычный друг» обозначает духовно близкого (понимающего тебя) человека.

Выражения, которые не требуют специального перевода, но не имеют аналогов в русском языке:

在家靠父母，出口靠朋友。- Дома опирайся на родителей, вышел за ворота - опирайся на друзей.

Существует несколько выражений в китайском языке, имеющих сходное значение. Например, часто используемого в межнациональном общении:

а) верность, самопожертвование:

患难见真情 (huànnàn jiàn zhēnqíng) - беда видит правду;

岁寒知松柏，患难见交情。- в холодное время узнается сосна и кипарис, в беде - дружба;

路遥知马力，患难识至交。- конь познаётся в езде, а друг в беде;

不打不成相识 - без драки друга не узнаешь.

Аналог данного выражения в русском языке: «Друг познается в беде», что означает - проявить себя верным другом в тяжелой жизненной ситуации.

\section{б) ценность дружбы, ее крепость:}

为财而生，不如为友而死。- чем жить для богатства， лучше умереть за друга - «Друг дороже денег» (Деньги приходят и уходят, верный друг остаётся) навсегда).

酒肉朋友 - друзья - пока есть вино и мясо.

\section{в) искренность дружбы:}

炼铁需要有硬火，交友需要有诚心。一 - Для производства чугуна нужен жесткий огонь, дружбе требуется чистое сердце - Друг - это одна душа, живущая в двух телах.

\section{г) характеристика человека:}

观其友，知其人。- хочешь узнать человека - погляди на его друзей - Скажи мне кто твой друг и я скажу тебе кто ты.

При этом существуют устойчивые выражения, которые не имеют аналога в русском языке, либо при дословном переводе принимают противоположное значение. Пример:

君子之交淡如水。- Дружба между аристократами как безвкусная вода. Выражение характеризует взаимоотношения, основанные на соблюдении правил этикета, в которых нет искренних дружеских отношений;

可以共患难，不可以共欢乐。- можно вместе переносить невзгоды, но нельзя вместе делить радость. В данном выражении при переводе возникнет затруднение понимания смысла выражения, при этом значение выражения: «Люди забыли, что к друзьям надо обращаться не только в трудную минуту, но делить с ними приятные, радостные события».

Таким образом, в нашем исследовании приведены устойчивые выражения, используемые в межнациональном и социокультурном общении на трансграничной территории города Благовещенска. Исследованы фразеоматизмы со смысловым компонентом «друг» русского и китайского языков, интерпретация которых невозможна без историко-культурного анализа.

Исследование даёт возможность познать русские и китайские фразеологизмы со смысловым компонентом «друг», их общие и индивидуальные языковые свойства, способствует успешной обоюдной коммуникации между народами двух стран. 


\section{ЛИТЕРАТУРА}

1. Виноградов В. В. 06 основных типах фразеологических единиц в русском языке [Текст] / В. В. Виноградов. Избранные труды. Лексикология и лексикография. - М.,1977. - С. 140.

2. Войнова Л.А., Жуков В.П., Молотков А.И. Фразеологический словарь русского языка / Л.А. Войнова, В.П. Жуков, А.И. Молотков. — 4-е изд., стереотип. -М.: Рус. яз., 1986. - 543с.

3. Ма Гофань. Краткий анализ китайской фразеологии / Ма Гофань. — Ляонин: Изд-во Народа, 1958. -72 с.

4. Мокиенко В.М. Славянская фразеология: Уч. пособие для филол. специальностей ун-тов / В.М. Мокиенко. — М.: Высшая школа, 1980. — 207 с. (5)

5. Трансграничье в изменяющемся мире // Журнал. Забайкальский государственный гуманитарно-педагогический университет им. Н. Г. Чернышевского. Чита. 2010. № 1. [Электронный ресурс] http://elibrary.ru/title items.asp?id=31023

6. Чжан Шоукан. Фразеологический словарь китайского языка / Чжан Шоукан. — Пекин: 2000. — 606 c.

7. Чжоу Цзянь. История исследования китайского словосочетания / Чжоу Цзянь. - Пекин:Изд-во Народа, 1998. — 50 c.

8. Ши Ши. Анализ китайской фразеологии / Ши Ши. — Сычуань: Изд-во Народа, 1979. — 577 с.

9. Идиомы в китайском языке - Китайский Центр Переводов в Санкт-

10. Петербурге [эектронный ресурс] https://chinese-russian.ru/publications.php/?publications=73.

11. Молчкова Л.В. Фразеоматизмы как продукт работы фразеоматического кода \І Современные проблемы науки и образования. -2014.- №4 \Iscince-education.ru

(с) Янь Юйчжуан (13614582298@mail.ru), Ладисова Ольга Владимировна (olga-ladisova@yandex.ru).

Журнал «Современная наука: актуальные проблемы теории и практики»

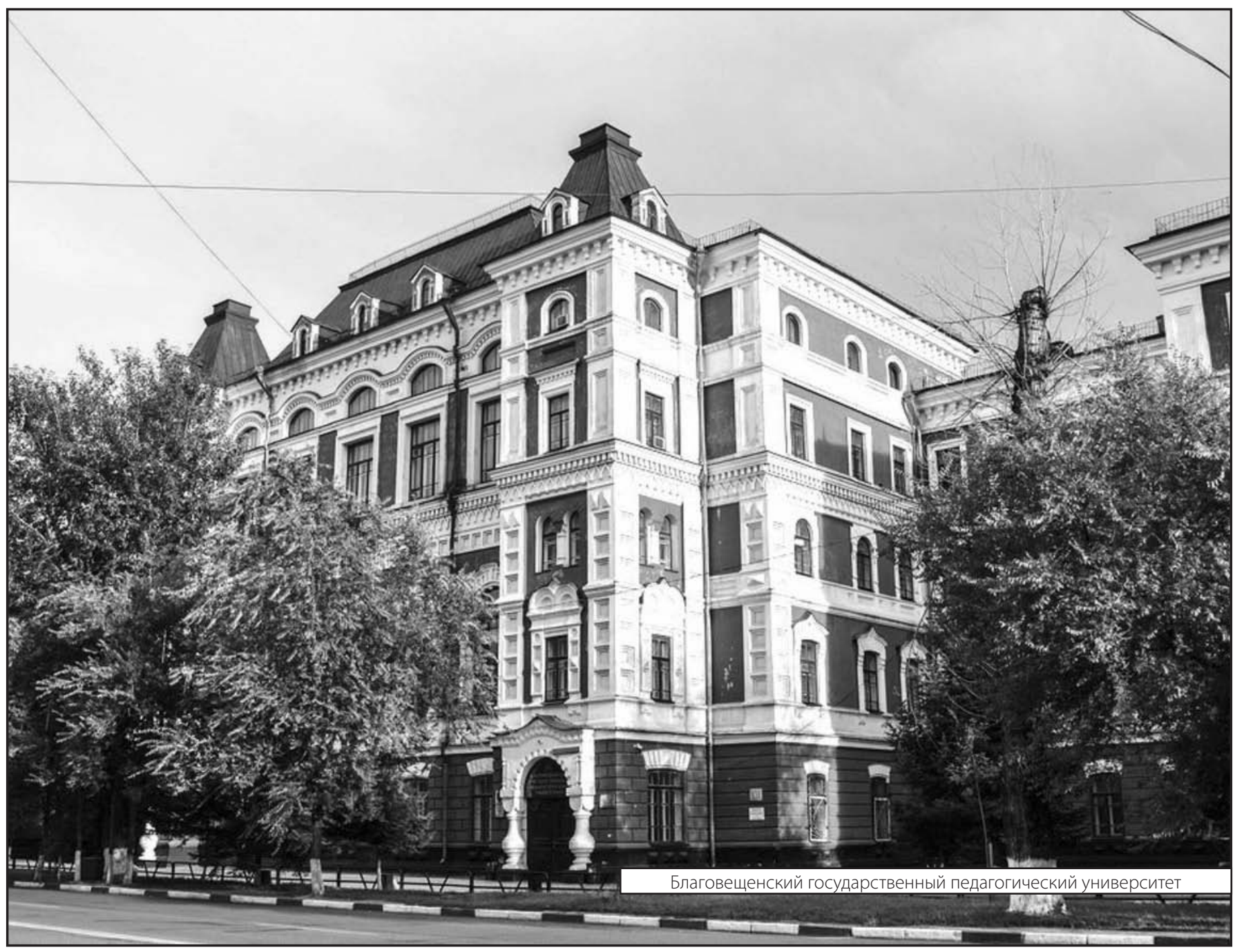

